Annals of Warsaw University of Life Sciences - SGGW

Land Reclamation No 41, 2009: 41-48

(Ann. Warsaw Univ. of Life Sci. - SGGW, Land Reclam. 41, 2009)

\title{
Transport modelling and monitoring research use for efficiency assessment of vertical barrier surrounding old sanitary landfill
}

\author{
EUGENIUSZ KODA, EDWARD WIENCŁAW \\ Department of Geotechnical Engineering, Warsaw University of Life Sciences - SGGW, Poland
}

LIVIO MARTELLI

Facolta di Ingegneria, Universita Politecnica delle Marche, Ancona, Italy

\begin{abstract}
Transport modelling and monitoring research use for efficiency assessment of vertical barrier surrounding old sanitary landfill. The paper describes the results of numerical modelling of pollution transport and groundwater quality monitoring for the old sanitary landfill where advanced protection system have been introduced. The protection system consists of the vertical bentonite barrier and peripheral leachate drainage. The GMS/FEMWATER numerical program has been used for groundwater flow and transport simulation. The local monitoring program includes chemical analyses of leachates, surface and groundwater as well as groundwater level observations. The modelling and monitoring results were aimed at the assessment of the vertical barrier effectiveness of groundwater protection in landfill surroundings. These analyses were performed for Radiowo landfill located nearby Warsaw. This object has been existing since 1962, and the permission for its exploitation was extended to the end of the year 2009. Remedial works of the landfill has been conducted since 1998 and they includes: the vertical bentonite barrier, the leachates drainage system, the leachate re-circulation system, the mineral cover, the degassing system as well as the regulation of water relations in surroundings. The influence of remedial works on the groundwater quality on landfill surroundings has also been analysed in the paper.
\end{abstract}

Key words: old landfill, modelling, pollutant migration, water monitoring, vertical barrier.

\section{INTRODUCTION}

Sanitary landfill is a specific bioreactor in which wastes are decomposed under influence of aerobic and anaerobic conditions and microorganisms in chemical, physical and biological processes. Rainwater penetrates the wastes and dissolves products in the above-described biochemical processes and forms leachates. The chemical composition and physical properties of leachates originating from the sanitary landfill depend on: kind of stored wastes, climatic conditions, age of the landfill, the way in which wastes are disposed of and the landfill exploitation phase.

Migration of the pollutants depends on geological conditions, which can be favorable to the transport of water and the substances it carries (large thickness of permeable layers, high hydraulic gradients) or it can completely stop and keep the transport away from the landfill (impermeable layers, low gradients).

In Poland there is still a large number of sanitary landfills where environmental protection standards are not fulfilled. 
Therefore, on these areas, the remedial worksaimed atprotecting theenvironment against progressive degradation should be carried out immediately. The example of engineering solutions of groundwater protection (cut-off bentonite barrier and peripheral drainage for leachate collection) applied for remediation of large embankment sanitary landfill in Radiowo is presented in the paper. In the case of the analyzed landfill, the basic remedial problem is connected with protection against leachate migration and groundwater pollution. The schemes of the old landfill before and after remedial works are presented in Figure 1. In the future, it is envisaged that the Radiowo landfill will be adapted for recreation purposes (bicycle lanes, ski-lift, view points).

The assessment of remedial works efficiency was performed with the use of numerical transport modeling and analysis of groundwater quality monitoring in the landfill surroundings. FEMWATER numerical program has been used to solve the flow and transport problem.

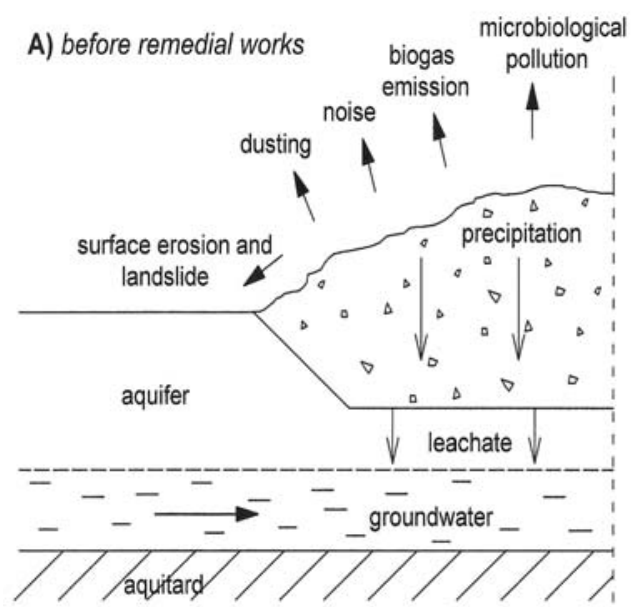

The control tests of the vertical barrier material and subsoil were performed to determine permeability parameters for the numerical model. The results of the groundwater monitoring were used for verification of the numerical model (Wiencław and Koda 2004; Koda et al. 2009). It is observed that, after closing of the vertical barrier and construction of leachate drainage, the pollution concentration has been directed towards the groundwater flow. The modelling and monitoring results allow to estimate the effectiveness of remedial works, these have been carried out at the landfill.

\section{SITE CHARACTERISTICS}

The Radiowo landfill is located in the NW part of Warsaw. It started to operate in 1962 and no protection system was installed there at that time. Mixed municipal solid wastes were disposed there up to 1991. Since 1992 only noncomposted wastes, i.e.: glass, plastics, textiles and scrap, have been stored

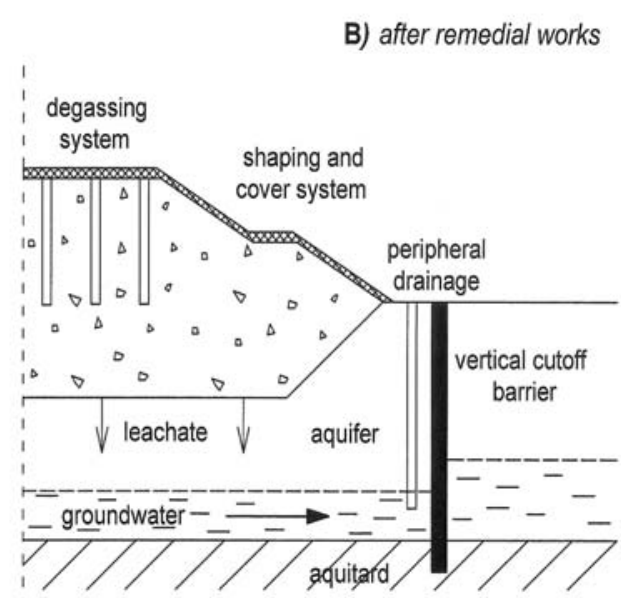

FIGURE 1. The old landfills schemes before and after remedial works performance 
there. It covers the area of approximately 16 ha and is almost $60 \mathrm{~m}$ high. Since 1998, remedial works have been carried out on the landfill. They include, among other things: shaping and planting of the slopes, stability reinforcement solution, mineral capping, cut-off barrier and peripheral leachate drainage protecting groundwater pollution as well as leachate recirculation and degassing systems. It is expected that the landfill will be closed down in 2009.

The landfill subsoil consists of sandy soils, 2-5 m thick, locally to the depth of $20 \mathrm{~m}$. In the upper part they are represented by dense sands, in the deeper part - by well-graded sands (from dense to coarse). This layer forms the first groundwater level with the groundwater table at the depth of $0-2 \mathrm{~m}$ below surface level. Water is supplied to this layer mainly by infiltration of precipitation and water inflow from the forest area located in the SE. Dewatering trenches from the $\mathrm{NE}$ and $\mathrm{W}$ parts, as well as a stream (from the $\mathrm{N}$ ), compose a local drainage system for the first groundwater layer. Leachates from the landfill and rain water from the compostory area are pumped to the landfill surface (re-circulation system).

The vertical bentonite barrier surrounding the landfill was constructed within 1999-2000. The $0.6 \mathrm{~m}$ wide bentonite barrier was established at the depth of $2 \mathrm{~m}$ below the top of clayey soils, i.e. 3.5-22.0 $\mathrm{m}$ below surface level. This aquitard layer consists of boulder and Tertiary clays. Closure of the bentonite barrier contributed to significant improvement in the quality of the first groundwater layer and surface water in ditches. Large improvement in the surface water quality is visible at the first sight - small amounts of samples of groundwater water are colorless (in the past it was a brownish stinking liquid).

\section{THE NUMERICAL MODEL OF POLLUTANT TRANSPORT}

The numerical model of groundwater flow was constructed with the use of GMS software (EMRL, 2005). The basis of the model is the 3-D solution of the task of groundwater flow and pollutant transport. Numerical modelling was focused on the assessment of the vertical barrier influence on hydrogeological conditions in the Radiowo landfill area.

The governing Richards' partial differential equation is used in FEMWATER program to describe groundwater flow:

$$
\nabla\left[k_{r} k_{S}(\nabla h+\nabla z)\right]+q=F \frac{\partial h}{\partial t}
$$

where:

$k_{r}$ - the relative hydraulic conductivity, $k_{s}$ - saturated hydraulic conductivity tensor,

$h$ - the pressure head,

$q$ - the source/sink discharge,

$t$ - time,

$F=\partial \theta / \partial \mathrm{h}-$ the differential water capacity,

$\theta$ - the volume moisture content.

Generally, it can be assumed that: $F, \theta$ and $k_{r}$ are functions depending on $h$. In the model, these relations were defined as function described by van Genuchten (1980).

The governing equations used in the FEMWATER model for transport 
are worked out based on the continuity of mass and flux laws. In the presented model, the transport process wasrespected as the advective-dispersive migration of a single dissolved indicator $\left(\mathrm{Cl}^{-}\right)$. It can be described by the equations:

$$
\begin{aligned}
& \theta \frac{\partial C}{\partial t}+V \cdot \nabla C-\nabla \cdot(\theta D \cdot \nabla C)=0 \\
& \theta D=a_{T}|V| \delta+\left(a_{L}-a_{T}\right) \frac{V V}{|V|}
\end{aligned}
$$

where:

$V$ - the discharge velocity vector (in Darcy flux),

$C$ - the material concentration in aqueous phase,

$t$-time,

$D$ - the dispersion coefficient,

$\alpha_{T}-$ the transversal dispersivity,

$\alpha_{L}-$ the longitudinal dispersivity,

$\delta$ - Kroneckers delta.

The analyzed technical solution for the model simulation consists of the protection system including the vertical barrier to stop leachate outflow from the landfill. The total area covered by the model is approximately 88 ha, including 16 ha of the landfill area (Wienclaw and Koda 2004).

Figure 2 presents assigned boundary conditions for the task. The analysed technical solution for the model simulation consists of the protection system concerning the vertical barrier. The model mesh consists of 8903 elements and 5289 nodes.

In the numerical model, taking into account geological deposits in subsoil of landfill surroundings, four landfill subsoil materials were distinguish. Beginning

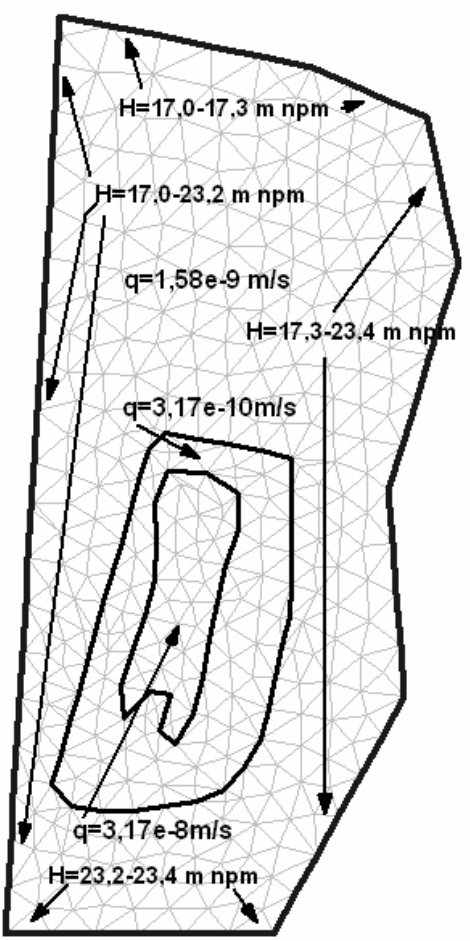

FIGURE 2. Boundary conditions for the numerical model of Radiowo landfill

from the older to younger (occurred directly below surface level), these are:

- Tertiary clays, with coefficient of hydraulic conductivity $k_{s}=5 \cdot 10^{-9} \mathrm{~m} / \mathrm{s}$,

- sandy clays, with coefficient of hydraulic conductivity $k_{S}=1 \cdot 10^{-7} \mathrm{~m} / \mathrm{s}$,

- variety grained sands, with hydraulic conductivity coefficient $k_{S}=5 \cdot 10^{-4} \mathrm{~m} / \mathrm{s}$,

- dense sands, with coefficient of hydraulic conductivity $k_{s}=5 \cdot 10^{-5} \mathrm{~m} / \mathrm{s}$.

The parameter values of unsaturated zone, demanded in the numerical model, for sands were accepted on the basis of the literature data (Carsel and Parrish 1988). They were, as follows:

- differential water capacity, $\mathrm{F}=0.0725$,

- volume water capacity $\theta$, reached from $\theta=0.045$ for $h=-4 \mathrm{~m}$ to $\theta=$ $=0.36$ for $h=0$, 
- relative conductivity, reached from $k_{r}=0$ for $h=-4 \mathrm{~m}$ to $k_{r}=1$ for $h=0$.

\section{WATER QUALITY MONITORING}

Analysis of water quality on surroundings is conducted according to local monitoring system which includes:

- 17 piezometers used to control the first groundwater layer,

- 1 deep well used to control the second water-bearing layer,

- 6 sampling points situated at surface watercourses (ditches),

- 4 sampling points of raw leachates,

- 1 sampling point of rainwater from the compostory area.

This network of points enables the appropriate control and estimation of the water quality. Chemical analysis for underground water has been conducted since 1997 . The analysis of water quality results reveals that introduction of the vertical barrier has positively changed the basic parameters of the first groundwater layer (Koda 2004). Detailed results of the monitoring research and its analysis are presented in annual reports.
The results of the groundwater monitoring were used for verification of the numerical model.

\section{DISCUSSION OF MONITORING AND MODELLING RESULTS}

The technical works conducted according to reclamation project, including the introduced in 2000 vertical bentonite barrier (it was closed in Nov. 2000) and drainage system to separate leachates from the landfill helped to obtain significant improvement in the quality of groundwater and surface water in the vicinity of the landfill. Table 1 shows the influence of the above-mentioned reclamation operations, especially the influence of vertical bentonite barrier on the quality of groundwater in the aquifer layer during the years 2000-2007. The obtained results show that construction of the vertical barrier (see Table 1) significantly improved the water quality. The presented results have been obtained based on piezometer No 7A, where the vertical barrier was closed.

TABLE 1. The influence of the vertical barrier on groundwater quality in piezometer P-7A

\begin{tabular}{|c|c|c|c|c|c|c|}
\hline \multirow{2}{*}{ Pollution indicator } & \multirow{2}{*}{ Unit } & \multicolumn{5}{|c|}{ Date / Concentration of pollutants } \\
\hline & & 11.07 .2000 & \multirow{9}{*}{ 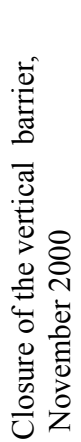 } & 20.06 .2001 & 23.11.2004 & 20.03.2008 \\
\hline Electr. conductivity & $\mu \mathrm{S} / \mathrm{cm}$ & 10830 & & 8370 & 4400 & 1178 \\
\hline $\mathrm{BOD}_{5}$ & $\mathrm{mg} \mathrm{O}_{2} / \mathrm{dm}^{3}$ & 650 & & 75 & 50 & 14,0 \\
\hline $\mathrm{COD}_{\mathrm{Cr}}$ & $\mathrm{mg} \mathrm{O}_{2} / \mathrm{dm}^{3}$ & 1758 & & 226 & 194 & 96,1 \\
\hline Ammonium nitrogen & $\mathrm{mg} \mathrm{N}_{\mathrm{NH}_{4}} / \mathrm{dm}^{3}$ & 97,7 & & 14,1 & 6,2 & 0,07 \\
\hline Chlorides & $\mathrm{mg} \mathrm{Cl}^{-} / \mathrm{dm}^{3}$ & 2374 & & 1595 & 530 & 42,1 \\
\hline Sulphates & $\mathrm{mg} \mathrm{SO}_{4}{ }^{2-} / \mathrm{dm}^{3}$ & 690 & & 630 & 450 & 278 \\
\hline Copper & $\mathrm{mg} \mathrm{Cu} / \mathrm{dm}^{3}$ & 2,1 & & 0,600 & 0,261 & 0,094 \\
\hline Lead & $\mathrm{mg} \mathrm{Pb} / \mathrm{dm}^{3}$ & 0,2 & & 0,05 & 0,006 & $<0,004$ \\
\hline
\end{tabular}


The numerical modeling by of pollutant migration in the first groundwater layer as a map of chlorides concentration before the closure of the vertical bentonite barrier is shown in Figure 3, whiles the situation after 5 years later, is presented in Figure 4.

In Figure 4 the movement of pollution-slick towards groundwater flow direction is observed. Maximum chlorides concentration in the slick has been reduced significantly as a result of dilution. It is predicted that the chlorides concentration will be reduced by $2-3$ times during the next 15 years, while total elimination of chlorides pollutions will take place after ca 30 years from the closure of bentonite barrier.

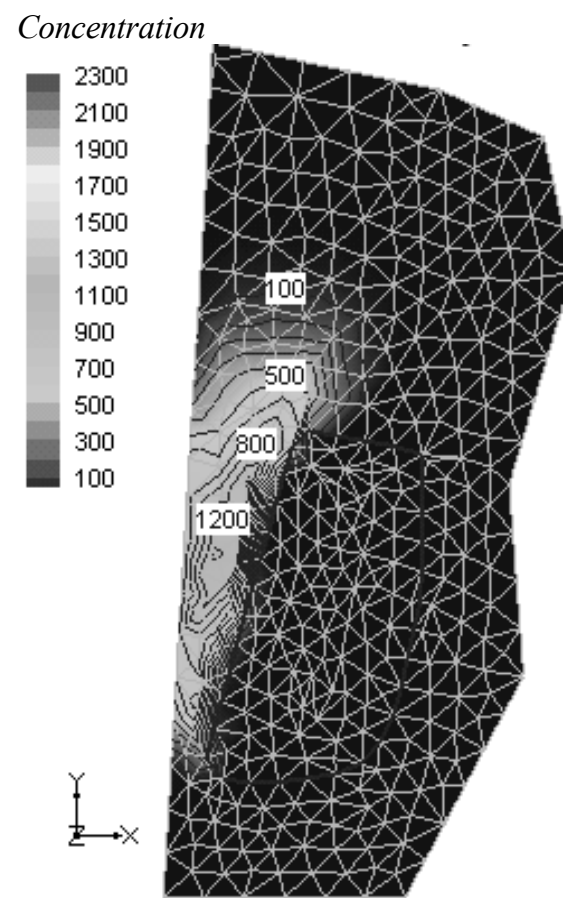

FIGURE 3. Chlorides concentration ( $\mathrm{mg} \mathrm{Cl}^{-} / \mathrm{dm}^{3}$ ) at the first groundwater layer before the vertical barrier construction

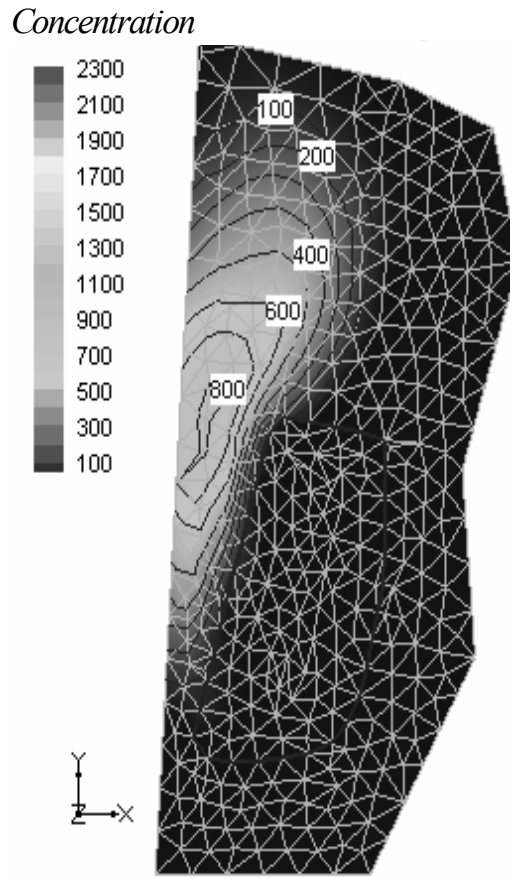

FIGURE 4. Chlorides concentration $\left(\mathrm{mg} \mathrm{Cl}^{-} / \mathrm{dm}^{3}\right)$ at the first groundwater layer 5 years after the vertical barrier construction

Verification of modeling results has been done based on water monitoring in the landfill surroundings. The Figure 5 and Figure 6 present spatial distribution of chlorides concentration for two periods, i.e. before and 5 years after the closure of the vertical bentonite barrier.

Comparing the maps of chlorides distribution received from numerical modeling and monitoring, one can observe the confinement of polluted zone and decrease in maximum value of chlorides concentration. Pollution movements can significantly affect water quality in outflow direction. After 5 years from the vertical barrier closure, the maximum concentration was moved from the zone of piezometer No 7A to the zone of piezometer No 11A (Fig. 7). 


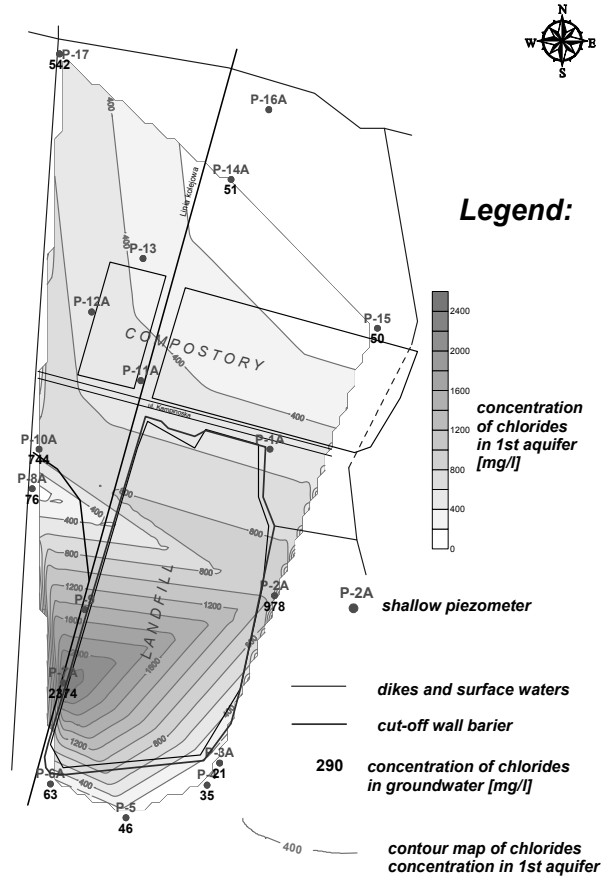

FIGURE 5. Chlorides concentration $\left(\mathrm{mg} \mathrm{Cl}^{-} / \mathrm{dm}^{3}\right)$ at the first groundwater layer before the vertical barrier construction, acc. to monitoring results

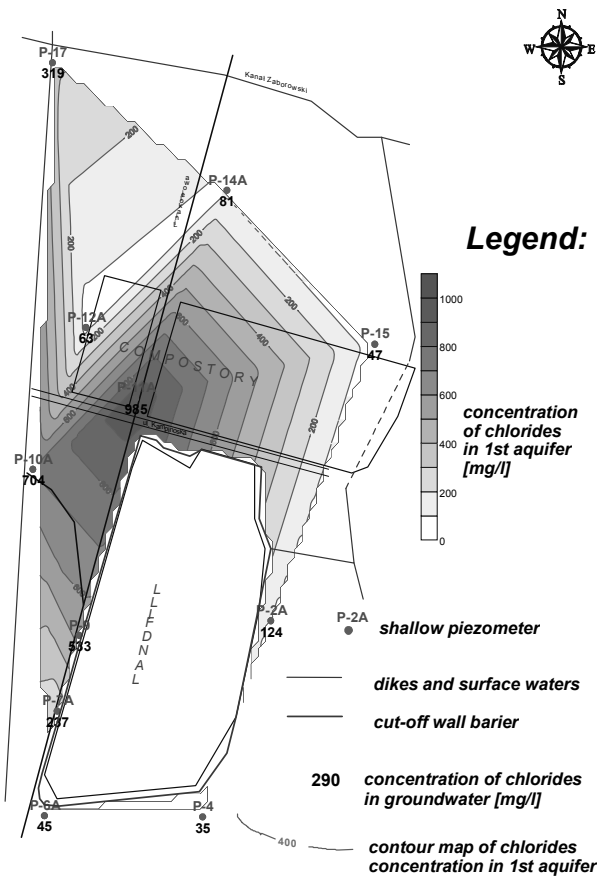

FIGURE 6. Chlorides concentration $\left(\mathrm{mg} \mathrm{Cl}^{-} / \mathrm{dm}^{3}\right)$ at the first groundwater layer 5 years after the barrier construction, acc. to monitoring results

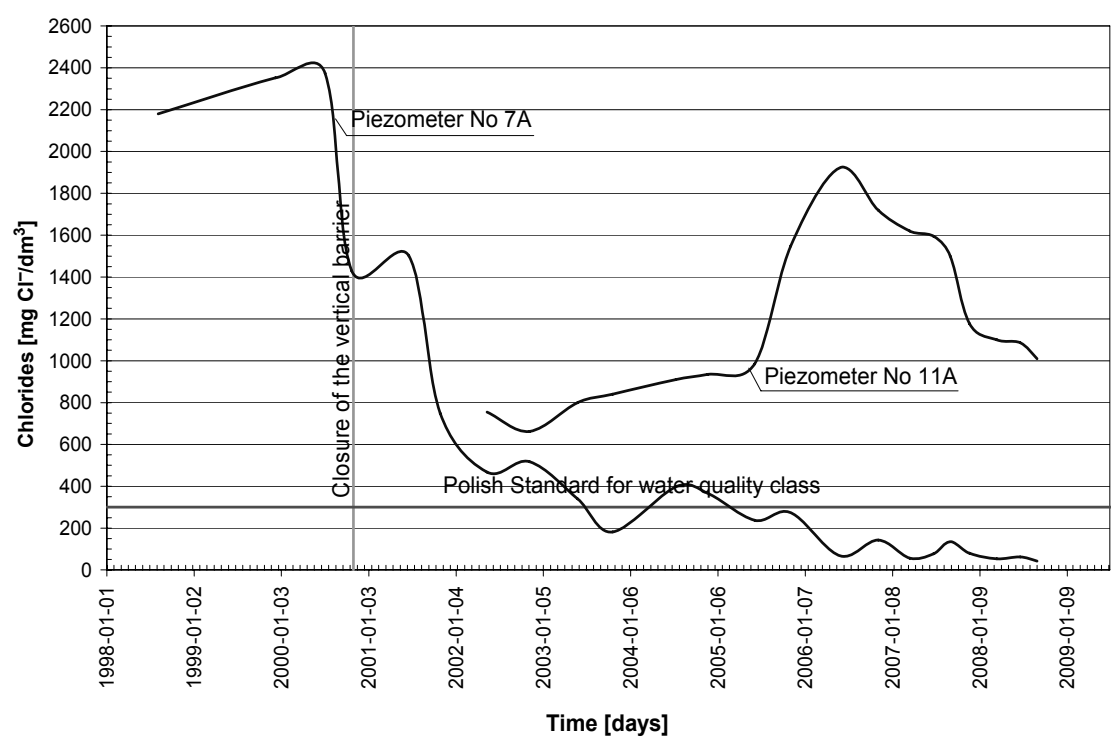

FIGURE 7. Moving of the maximum chlorides concentration (in $\mathrm{mg} \mathrm{Cl}^{-} / \mathrm{dm}^{3}$ ) towards flow in the first groundwater layer from piezometer No 7A to piezometer No 11A 


\section{CONCLUSIONS}

The remedial works carried out on the Radiowo landfill proceed in the right direction and should be brought to the end soon. After closing the vertical barrier, the quality of groundwater (first layer) has improved. Simultaneously, after closing the vertical barrier the main pollution concentration has been moving towards groundwater flow direction.

Numerical modelling is useful for the assessment of the vertical barrier influence on the groundwater flow and quality. The results of numerical modelling for the Radiowo landfill, presented and analyzed in the paper, proved the isolation role of the vertical bentonite barrier. The groundwater transport modelling results correspond to the monitoring measurements.

\section{REFERENCES}

CARSEL R.F., PARRISH R.S. 1988: Developing joint probability distribution of soilwater retention characteristics. Water Resources Research, Vol. 24, No 5, 755-760.

EMRL 6.0., 2005: Groundwater Modelling System - tutorial volume I-IV, Birgham Young University, Provo UT.

KODA E. 2004. Local water quality monitoring on surroundings of the sanitary landfill. Annals of Warsaw Agricultural University - SGGW, Land Reclamation, No 35a: 131-144.

KODA E., GOLIMOWSKI J. AND WIENCŁAW, E. 2009: Assessment of efficiency of the old landfill protection system based on transport modelling and monitoring research. Proceedings of the 17th International Conference on Soil Mechanics and Geotechnical Engineering, Alexandria (in print).
Van GENUCHTEN M.T. 1980: A closed-form equation for predicting the hydraulic conductivity of saturated soils. Soil Science Society Journal, No 44: 892-898.

WIENCŁAW E., KODA E. 2004: Groundwater flow modeling for old landfill with vertical barrier. Annals of Warsaw Agricultural University - SGGW, Land Reclamation, No 35a: 229-336.

Streszczenie: Wykorzystanie modelowania transportu i monitoringu jakości wód do oceny efektywności bariery pionowej otaczajacej stare sktadowisko odpadów. W artykule przedstawiono wyniki numerycznego modelowania transportu zanieczyszczeń i monitoringu jakości wód w rejonie rekultywowanego składowiska odpadów. Do modelowania wykorzystano program numeryczny GMS/FEMWATER. Celem modelowania i monitoringu jest ocena skuteczności zabiegów rekultywacyjnych, w tym głównie pionowej przesłony przeciwfiltracyjnej, w ochronie wód gruntowych na terenach przyległych do składowiska. Obliczenia przeprowadzono dla składowiska Radiowo k/Warszawy. Składowisko powstało w 1962 roku, a od 1992 roku jest miejscem deponowania odpadów balastowych z kompostowni. Od 1994 roku na obiekcie prowadzone sa prace rekultywacyjne obejmujące m.in. wykonanie: bentonitowej przesłony przeciwfiltracyjnej, systemu drenażowego i recyrkulacji odcieków, kształtowanie skarp i systemu odgazowania. Monitoring lokalny wód obejmuje analizy fizykochemiczne odcieków, wód podziemnych i powierzchniowych. W artykule analizowano wpływ wykonanych zabiegów rekultywacyjnych na warunki przepływu wód gruntowych i transportu zanieczyszczeń w rejonie składowiska.

\section{MS. received May, 2009}

\section{Authors' address:}

Eugeniusz Koda

Zakład Geotechniki, Katedra Geoinżynierii

Wydział Inżynierii i Kształtowania Środowiska, SGGW

02-776 Warszawa, 159 Nowoursynowska St.

Poland 